\title{
EFFECTIVENESS OF CRITICAL MULTILITERATION MODEL WITH RADEC MODEL ON THE ABILITY OF WRITING EXPLANATORY TEXT
}

\author{
Dadan Setiawan ${ }^{1}$, Tatat Hartati ${ }^{2}$,Wahyu Sopandi ${ }^{3}$ \\ Universitas Pendidikan Indonesia
}

\begin{abstract}
Developing students' skill in writing scientific explanation is one of the main goals in education. The purpose of this study is to determine the effectiveness of the critical multi-literation model and the RADEC model on the ability in writing explanatory text of elementary school students. This research is conducted on 5th grade students of SDN 122 Cijawura, Buah Batu, Bandung. The samples used in this study are 39 students in the experimental class 1 that used the critical multi-literation model and 38 students in the experimental class 2 that used the RADEC model. The research method used in this study is a quasi-experimental method with a non-equivalent pre-test and post-test control group design. Based on the results of the study, it is found that the pre-test score in the experimental class 1 is 36.6 and the post-test result is 78. Whereas in the experimental class 2 the pre-test score obtained is 48.1 and the post-test score is 68.9. Furthermore, from the results of the independent sample test, the results of the post-test mean difference test are sig $=0.018$, so it can be concluded that there are significant differences in the ability to write explanatory text of students between the experimental class 1 and the experimental class 2. Based on these results, the multi-literation model critical is more effective than the RADEC model in developing the ability in writing explanatory text in elementary school students.
\end{abstract}

Keyword: Writing explanatory text, critical multi-literation model, RADEC model

\begin{abstract}
Abstrak: Mengembangkan keterampilan siswa dalam menulis penjelasan ilmiah adalah salah satu tujuan utama dalam pendidikan. Tujuan dari penelitian ini adalah untuk mengetahui efektivitas model multiliterasi kritis dengan model RADEC terhadap kemampuan menulis teks eksplanasi siswa sekolah dasar. Penelitian ini dilakukan pada siswa kelas 5 SDN 122 Cijawura, Kecamatan Buah Batu, Kota Bandung. Adapun sampel yang digunakan dalam penelitian ini berjumlah 39 siswa di kelas eksperimen 1 yang menggunakan model multiliterasi kritis dan sebanyak 38 siswa di kelas eksperimen 2 yang menggunakan model RADEC. Metode penelitian yang digunakan dalam penelitian ini adalah metode kuasi eksperimen dengan desain Non-equivalent pretest postest control grup design. Berdasarkan hasil penelitian, didapatkan hasil bahwa skor pretest pada kelas eksperimen 1 sebesar 36,6 dan hasil posttest sebesar 78. Sedangkan pada kelas eksperimen 2 skor pretest yang diperoleh sebesar 48,1 dan skor posttest sebesar 68,9 . Selanjutnya, dari hasil uji independent sample test diperoleh hasil uji beda rerata posttest yaitu nilai sig $=0,018$, sehingga dapat disimpulkan bahwa terdapat perbedaan yang signifikan kemampuan menulis teks eksplanasi siswa antara di kelas eksperimen 1 dengan di kelas eksperimen 2. Berdasarkan hasil tersebut, model multiliterasi kritis lebih efektif daripada model RADEC dalam mengembangkan kemampuan menulis teks eksplanasi siswa sekolah dasar.
\end{abstract}

Kata Kunci: Menulis teks eksplanasi, model multiliterasi kritis, model RADEC

'Universitas Pendidikan Indonesia, Email: dsetiawan[3国upi.edu

2Universitas Pendidikan Indonesia, Email: tatat国upi.edu

${ }^{3}$ Universitas Pendidikan Indanesia, Email: wsapandi国upi.edu 


\section{PENDAHULUAN}

Menulis merupakan salah satu keterampilan berbahasa yang harus dikuasai oleh siswa. Menulis merupakan tingkatan tertinggi dari keterampilan berbahasa yang lainnya yaitu keterampilan membaca, menyimak dan berbicara (Paul, 2007). Selain itu, menulis merupakan kegiatan yang sangat penting karena dengan kegiatan menulis dapat membantu perkembangan sosial, mengembangkan kreativitas siswa, dan meningkatkan keterampilan berpikir kritis siswa (Bakry \& Alsamadani, 2015). Menulis juga merupakan suatu proses atau aktivitas yang produktif karena dapat menghasilkan produk berupa karya tulis yang dapat dijadikan sebagai alat penyampai pesan atau komunikasi (Cahyani, 2012; Tarigan, 2013; Abidin, 2015; Özdemir \& Aydin, 2015).

Pada dasarnya, proses menulis memerlukan tingkat berpikir yang tinggi dan memerlukan kreativitas agar tulisantulisan yang dihasilkan memiliki kualitas yang baik dan menarik. Keterampilan menulis merupakan keterampilan yang harus dikuasai oleh siswa karena kegiatan menulis merupakan kegiatan yang selalu ada dalam setiap proses pembelajaran untuk memudahkan siswa dalam mengingat atau mempelajari sesuatu (Graham \& Hall, 2016). Agar siswa terampil menulis, siswa harus berlatih menulis secara terus-menerus menggunakan strategi yang tepat (CelceMurcia, 2001; Akkaya \& Kirmizi, 2010).

Menulis teks eksplanasi merupakan salah satu materi baru yang diajarkan di sekolah dasar sejak Kurikulum 2013 diberlakukan. Sehingga tidak jarang siswa merasa kesulitan dalam menulis teks eksplanasi karena materi teks eksplanasi termasuk kedalam materi baru. Oleh karena itu, keterampilan menulis teks eksplanasi siswa perlu ditingkatkan melalui tahapan belajar yang tepat (Emilia, 2012). Kegiatan menulis saat ini memang masih belum menjadi suatu hal yang digemari oleh siswa, sehingga kemampuan menulis siswa Indonesia masih termasuk kedalam kategori rendah (Abidin, 2012). Rendahnya keterampilan menulis disebabkan oleh beberapa faktor diantaranya adalah minimnya peran guru dalam membina siswa agar terampil dalam menulis (Abidin, 2012). Selanjutnya, minimnya motivasi juga menjadi faktor penyebab kemampuan siswa dalam menulis menjadi rendah (Graham \& Hall, 2016; Özdemir \& Aydın, 2015). Selain itu, penerapan strategi atau model pembelajaran yang kurang tepat juga bisa menjadi salah satu faktor yang mempengaruhi kemampuan siswa (Joyce \& Calhoun, 2011).

Rendahnya kemampuan menulis siswa khususnya di sekolah dasar perlu segera di atasi. Penelitian tentang kemampuan menulis teks eksplanasi sudah banyak dilakukan oleh peneliti lain yaitu seperti penelitian yang dilakukan oleh Seah (2015) penelitiannya bagus dalam hal pengembangan pola penggunaan bahasa dalam menulis teks eksplanasi. Namun, terdapat temuan dan kekurangan bahwa fokus pada pengembangan konseptual terkait konten yang akan ditulis tidak cukup untuk meningkatkan kemampuan siswa dalam menulis teks eksplanasi. Selanjutnya penelitian lain bagus dalam hal peningkatan kemampuan menulis teks eksplanasi melalui media gambar dan audio visual. Namun terdapat kekurangan yaitu penguasaan konsep dan penggunaan pola bahasa teks eksplanasi masih kurang (Andyani, Saddhono, \& Mujyanto, 2016; Lagur, 2016).

Penelitian tentang kemampuan menulis teks eksplanasi kebanyakan dilakukan pada siswa SMP dan SMA. Sangat jarang ditemui penelitian kemampuan menulis teks eksplanasi pada siswa sekolah dasar, sehingga pada penelitian ini, selain untuk memperbaiki kekurangan penelitian sebelumnya tentang teks eksplanasi, penelitian ini juga dapat memberikan kebaharuan penelitian yang menggambarkan kemampuan menulis teks eksplanasi siswa sekolah. 
TINJAUAN PUSTAKA

\section{Kemampuan Menulis}

Menulis merupakan salah satu keterampilan berbahasa yang harus dikuasai oleh siswa. Menulis merupakan tingkatan tertinggi dari keterampilan berbahasa yang lainnya yaitu keterampilan membaca, menyimak dan berbicara. Menulis merupakan aktivitas berpikir tingkat tinggi karena melibatkan system yang kompleks yaitu aspek kognitif, kreativitas, dan sikap. Dalam hal ini, menulis merupakan suatu proses atau aktivitas yang produktif karena dapat menghasilkan produk atau karya tulis yang dapat dijadikan sebagai alat penyampai pesan atau alat untuk berkomunikasi (Cahyani, 2012; Tarigan, 2013; Abidin, 2015; Özdemir \& Aydın, 2015). Selain itu, menulis merupakan kegiatan yang sangat penting karena dengan kegiatan menulis dapat mengembangkan keterampilan siswa dalam berpikir kritis dan kreatif (Bakry \& Alsamadani, 2015).

Pada dasarnya, proses menulis memerlukan tingkat berpikir yang tinggi dan memerlukan kreativitas agar tulisan yang dihasilkan memiliki kualitas yang baik. Keterampilan menulis, merupakan keterampilan yang harus dikuasai oleh siswa, mengingat kegiatan menulis merupakan kegiatan yang ada dalam setiap proses pembelajaran dengan tujuan untuk memudahkan siswa dalam mengingat dan atau mempelajari sesuatu (Graham \& Hall, 2016). Mengajarkan keterampilan menulis di sekolah dasar bukanlah suatu hal yang mudah. Untuk melatih siswa agar terampil dalam menulis membutuhkan waktu yang cukup, strategi yang tepat dan membutuhkan kesabaran dalam membimbing siswa ketika proses menulis (Pardo, 2006).

Sekait dengan penjelasan di atas, karena menulis bukanlah kegiatan yang sekali jadi, maka dalam praktik pembelajaran menulis, guru harus memberikan kesempatan kepada siswa untuk melakukan tahap pengecekan kembali dan mengeditnya jika terdapat kesalahan. Tahap tersebut penting dilakukan untuk meminimalisir kesalahan yang dilakukan oleh penulis (Hartati \& Cuhariah, 2015).

\section{Teks Eksplanasi}

Pada pembelajaran menulis di sekolah dasar, terdapat beragam jenis teks yang diajarkan kepada siswa. Berdasarkan Peraturan Menteri Pendidikan dan Kebudayaan No. 24 Tahun 2016 tentang Kompetensi Inti dan Kompetensi Dasar Pelajaran pada Kurikulum 2013, salah satu jenis teks yang diajarkan di sekolah dasar adalah teks eksplanasi. Teks eksplanasi merupakan teks yang termasuk dalam genre teks tanggapan.

Genre teks tanggapan, secara umum terdiri dari dua jenis yaitu teks transaksional dan teks ekspositori. Dilihat dari kedua jenis teks tangapan ini, teks eksplanasi termasuk dalam jenis teks ekspositori (Kemendikbud, 2014).

Banyak ahli yang berpendapat tentang definisi dari teks eksplanasi. Pada hakikatnya teks eksplanasi merupakan teks yang menjelaskan tentang proses terjadinya sesuatu dan mengapa sesuatu tersebut terjadi (Mahsun, 2014; Anderson \& Anderson, 1997a; Gerot \& Wignell, 1995; Derewianka, 1990). Hal yang dijelaskan dalam teks eksplanasi ini yaitu mengenai fenomena alam, sosial, budaya dan ilmu pengetahuan (Priyatni, 2014).

Teks eksplanasi memiliki fungsi untuk menjelaskan proses terjadinya suatu gejala atau fenomena yang terjadi. Selain itu, teks eksplanasi juga berfungsi sebagai sarana untuk memahami dunia dan cara kerjanya (Knapp \& Watkins, 2005). Dilihat dari pengertian dan fungsi teks eksplanasi, maka teks eksplanasi memiliki tujuan. Tujuan dari teks eksplanasi sendiri adalah untuk mengungkapkan secara jelas bagaimana proses terjadinya sesuatu, bagaimana cara kerja sesuatu, dan mengungkapkan bagaimana suatu fenomena itu bisa terjadi (Emilia, 2012).

Secara umum, teks eksplanasi terbagi dalam beberapa bagian yakni: (a) 
pernyataan umum; (b) bagian inti dari teks eksplanasi yang merupakan penjelasan tentang kejadian atau tahapan dari suatu proses; dan (c) penutup yang berisi kesimpulan atau interpretasi (Mahsun, 2014; Emilia, 2012; Anderson \& Anderson, 1997a).

\section{Model Pembelajaran Multiliterasi Kritis Model multiliterasi kritis} merupakan model pembelajaran hasil pengembangan dari konsep literasi kritis (Abidin, 2015). Konsep literasi kritis dikembangkan oleh Freire (2005) yang pada hakikatnya konsep literasi kritis adalah kemampuan untuk mengkritisi teks dari sudut pandang yang berbeda. Pada hakikatnya konsep multiliterasi dipandang sebagai konsep yang penting dalam abad ke-21. Konsep multiliterasi mendorong para guru untuk berperan sebagai desainer dan fasilitator dalam terjadinya proses belajar mengajar yang bermutu, bermakna dan menyenangkan karena dalam prosesnya guru mengakomodasi keberagaman yang dimiliki oleh siswa (Altas, 2014; Hesterman, 2011). Peran guru sebagai fasilitator dalam pembelajaran multiliterasi sejalan dengan pandangan Navehebrahim (2011) bahwa di era modern ini guru harus berperan sebagai fasilitator.

Model multiliterasi berorientasi pada pencapaian kompetensi abad ke-21 (Giampapa, 2010). Selain itu, penerapan konsep multiliterasi dalam pembelajaran juga dapat mengembangkan keterampilan siswa dalam menuangkan ide kedalam berbagai konteks (Alexander, DePalma, \& Ringer, 2016). Dalam praktiknya, model multiliterasi ini menggabungkan konsep multimodal, sehingga pembelajaran menjadi lebih bermutu dan bermakna (Silvers, Shorey, \& Crafton 2010). Banyak penelitian tentang penerapan model multiliterasi kritis dalam pembelajaran menulis dan hasilnya terbukti bahwa selain dapat meningkatkan kemampuan menulis siswa, melalui penerapan model ini juga dapat meningkatkan motivasi belajar dan kreativitas siswa dalam menulis
(Nurhalimah, 2016, Iskandar, Abidin, \& Yunansah, 2016; Dafit, 2017; Susilo \& Ramdiati, 2019).

Langkah-langkah model pembelajaran multiliterasi kritis yaitu: (a) curah gagasan; (b) menetapkan masalah; (c) membaca teks; (d) menemukan fakta dan opini; (e) menguji fakta dan opini; (f) menetapkan fenomena; (g) menganalisis fenomena; (h) memproduksi karya (Abidin, 2015).

\section{Model Pembelajaran RADEC}

Model pembelajaran RADEC dikembangkan oleh Sopandi (2017) dengan tujuan untuk meningkatkan kualitas pembelajaran dan mendorong siswa untuk menguasai kompetensi dan keterampilan abad ke-21 yang dibutuhkan. Model ini merupakan model yang sudah disesuaikan dengan konteks keindonesiaan. Model ini memiliki langkah-langkah pembalajaran yang dapat mendorong siswa untuk belajar secara aktif dan produktif.

Model RADEC dikembangkan atas dasar beberapa hal yaitu berikut. Pertama, model ini didasarkan pada tujuan pendidikan nasional yakni untuk mengembangkan segenap potensi yang dimiliki siswa menjadi manusia yang beriman kepada Tuhan, luhur, sehat, berpengetahuan, cakap, kreatif, mandiri, dan menjadi warga negara yang demokratis serta bertanggung jawab (Pemerintah Republik Indonesia, 2003). Kedua, model ini dikembangkan atas dasar teori kontruktivisme. Menurut Vygotski (dalam Sopandi, 2017) mengemukakan bahwa kemampuan kognitif pada anak-anak dapat berkembang melalui interaksi dengan lingkungan sosial. Pada teori ini, dikenal dengan istilah Zona Pengembangan Proksimal (ZPD). Jadi dalam proses pembelajaran, ada masa dimana siswa perlu belajar secara mandiri tentang suatu konsep materi pelajaran tanpa bantuan oleh orang lain. Hal ini bertujuan untuk melihat kemampuan sebenarnya siswa dan ada masa dimana siswa perlu bantuan orang lain untuk mengembangkan kemampuan 
potensialnya. Atas dasar teori tersebut, maka dalam proses pembelajaran guru harus melakukan pembelajaran diantara hal tersebut.

Model pembelajaran RADEC memiliki beberapa keunggulan diantaranya yaitu dapat mendorong siswa untuk beroleh keterampilan abad ke-21. Pada abad ke-21 ini ada beberapa kompetensi yang harus dimiliki oleh manusia yaitu pemahaman konseptual, berpikir kritis, kolaborasi dan komunikasi, dan berpikir kreatif (Morocco, et. al., 2008). Keunggulan model RADEC lainnya adalah tahapan dari model ini mudah untuk dipahami dan diingat oleh guru. Hal ini terbukti dari penelitian yang dilakukan oleh Sopandi dan Handayani (2019) yang hasilnya adalah sebanyak 97,2\% guru yang mengikuti pelatihan tertarik untuk mengimplementasikan model pembelajaran RADEC di sekolah karena mudah untuk dipahami dan hasil implementasi di sekolahnya pun dapat membantu siswa untuk membangun karakter, meningkatkan pemahaman konseptual siswa dan mendorong siswa untuk mengembangkan kompetensi abad ke-21.

Berikut ini adalah langkah-langkah model pembelajaran RADEC yaitu: (a) Read; (b) Answer; (c) Disscuss; (d) Explain; (e) Create (Sopandi, 2017).

\section{METODOLOGI PENELITIAN}

Metode penelitian yang digunakan dalam penelitian ini adalah metode penelitian kuasi eksperimen dengan desain Non-equivalent pretest postest control grup design. Sampel dalam penelitian ini berjumlah 77 siswa. Sebanyak 39 siswa di kelas eksperimen 1 yang menggunakan model pembelajaran multiliterasi kritis dan sebanyak 38 siswa di kelas eksperimen 2 yang menggunakan model pembelajaran RADEC. Sampel dalam penelitian ini adalah kelas VA dan VB di SDN 122 Cijawura. Sekolah tersebut terletak di Kecamatan Buah Batu, Kota Bandung. Siswa yang menjadi sampel dalam penelitian ini merupakan siswa yang secara kognitif berbeda-beda. Terdapat siswa yang secara kognitif berada pada level tinggi, terdapat siswa yang berada pada level menengah dan terdapat siswa yang secara kognitif berada pada level rendah.

Pengumpulan data kemampuan menulis teks eksplanasi siswa menggunakan intrumen tes dan rubrik penilaian. Rubrik penilaian kemampuan menulis teks eksplanasi dikembangkan oleh peneliti dengan mengacu pada pedoman penilaian yang dikembangkan oleh beberapa ahli bahwa hal yang dinilai dalam kemampuan menulis teks eksplanasi adalah teks eksplanasi yang dibuat harus sesuai dengan karakteristik teks eksplanasi dan kaidah bahasa teks eksplanasi (Rose, 2007; Knapp \& Watkins, 2005; Department of Western Australia, 1997a). Berikut ini adalah indikator penilaian kemampuan menulis teks eksplanasi yang dikembangkan oleh peneliti yaitu: (a) struktur teks eksplanasi; (b) karakteristik isi teks eksplanasi; (c) bahasa teks eksplanasi; dan (d) aspek mekanik.

Penelitian ini dilakukan selama delapan kali pertemuan. Pertemuan pertama, peneliti melakukan pretest untuk mengetahui kemampuan menulis teks eksplanasi siswa sebelum diberikan treatment. Teks eksplanasi yang dibuat siswa dalam penelitian ini adalah teks eksplanasi berjenis sequence explanation. Teks eksplanasi jenis sequence explanation merupakan jenis teks eksplanasi yang fokusnya menjelaskan tentang bagaimana proses terjadinya suatu fenomena. Alasan peneliti memilih teks eksplanasi jenis tersebut adalah karena teks tersebut merupakan jenis yang paling sederhana sehingga sesuai dengan tingkat anak sekolah dasar yang baru belajar mengenal jenis-jenis teks.

Pada pertemuan kedua sampai pada pertemuan ke tujuh siswa diberikan pembelajaran menggunakan model multiliterasi kritis. Setelah diberikan pembelajaran menggunakan model multiliterasi kritis, baru kemudian pada pertemuan ke delapan, siswa diberikan 
posttest untuk mengetahui kemampuan menulis teks eksplanasi siswa setelah diberikan treatment.

Setelah diperoleh data hasil pretest dan posttest, selanjutnya data dianalisis. Analisis hasil penelitian dilakukan menggunakan uji normalitas, uji homogenitas dan independent sampel test (uji $t$ ). Dalam pengolahannya, peneliti menggunakan program SPSS versi 20

\section{HASIL PENELITIAN DAN PEMBAHASAN \\ Kemampuan Menulis Teks Eksplanasi Menggunakan Model Multiliterasi Kritis Pretest dan Posttest}

Berdasarkan hasil skor posttest menunjukkan kemampuan menulis teks eksplanasi siswa lebih baik dibandingkan dengan hasil skor pretest. Pada tabel 1 dan tabel 2 di bawah ini, menunjukkan perbedaan kemampuan menulis teks eksplanasi siswa dilihat pada empat indikator yaitu struktur teks eksplanasi, isi, bahasa, dan aspek mekanik. Perbedaan tersebut dapat dilihat pada tabel berikut.

\section{Tabel 1. Pretest}

\begin{tabular}{lcccc}
\hline \multicolumn{1}{c}{ Pretest } & Struktur & Isi & \multicolumn{2}{c}{ Bahasa } \\
\hline Range & 50 & 50 & 50 & 50 \\
Minimum & 25 & 25 & 25 & 25 \\
Maximum & 75 & 75 & 75 & 75 \\
Mean & 44.23 & 34.61 & 37.82 & 30.76 \\
Std. Deviation & 12.114 & 14.751 & 16.091 & 12.11 \\
Variance & 146.76 & 217.61 & 258.94 & 146.7 \\
\hline
\end{tabular}

Berdasarkan tabel 1, menunjukkan bahwa kemampuan awal siswa dalam menulis teks eksplanasi termasuk dalam kategori kurang. Skor minimum dari setiap aspek menulis teks eksplanasi yang diperoleh siswa sebesar 25, sedangkan skor maksimum dari setiap aspeknya sebesar 75 . Aspek yang paling menonjol diantara empat indikator kemampuan menulis teks eksplanasi siswa adalah aspek struktur. Artinya kemampuan menulis teks eksplanasi siswa sesuai dengan struktur teks eksplanasi pada kegiatan pretest mendapatkan skor rata-rata tertinggi diantara aspek yang lainnya.
Tabel 2. Posttest

\begin{tabular}{lcccc}
\multicolumn{1}{c}{ Posttest } & Struktur & Isi & Bahasa & Mekanik \\
\hline Range & 50 & 50 & 50 & 75 \\
Minimum & 50 & 50 & 50 & 25 \\
Maximum & 100 & 100 & 100 & 100 \\
Mean & 89.1 & 75 & 82.69 & 65.38 \\
Std. Deviation & 13.806 & 15.174 & 18.275 & 20.371 \\
Variance & 190.62 & 230.26 & 334 & 414.98 \\
\hline
\end{tabular}

Berdasarkan data posttest, diketahui bahwa terdapat peningkatan kemampuan menulis setelah diberikan pembelajaran menggunakan model multiliterasi kritis. Skor minimum dari setiap aspek menulis teks eksplanasi kecuali aspek mekanik mengalami peningkatan yaitu semula skor minimum pada data pretest sebesar 25 setelah diberikan treatment naik menjadi 50. Kemudian pada skor maksimum yang semula mendapat skor 75 , setelah diberikan treatment naik menjadi 100. Aspek yang paling menonjol diantara empat indikator kemampuan menulis teks eksplanasi siswa adalah aspek struktur. Artinya kemampuan menulis teks eksplanasi siswa sesuai dengan struktur teks eksplanasi pada kegiatan posttest mengalami peningkatan tertinggi diantara aspek yang lainnya. Peningkatan dari setiap indikator kemampuan menulis teks eksplanasi siswa berdasarkan data pretest dan posttest dapat dilihat pada gambar di bawah ini yaitu sebagai berikut.

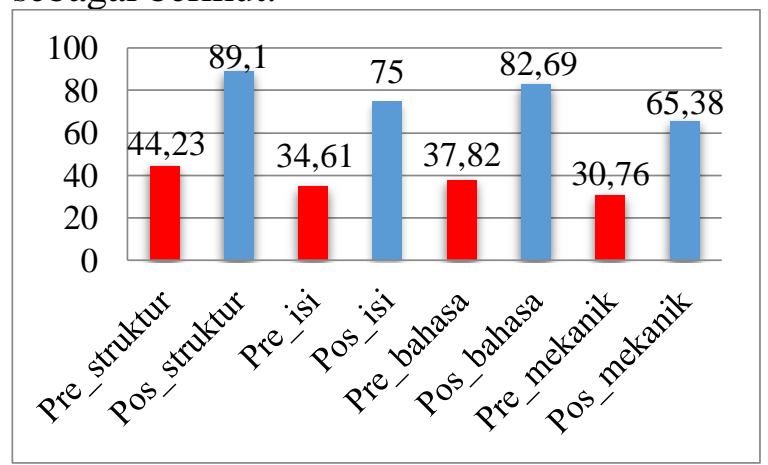

Gambar 1. Peningkatan Kemampuan Menulis Teks Eksplanasi Siswa

Berdasarkan gambar 1, data menunjukkan terjadi peningkatan pada setiap indikator kemampuan menulis teks eksplanasi. Peningkatan yang paling signifikan terjadi pada indikator struktur teks eksplanasi. Hal ini terlihat dari data pretest yaitu sebesar 44,23. Setelah diberikan pembelajaran menggunakan 
model multiliterasi kritis, terdapat peningkatan kemampuan menulis siswa pada aspek struktur. Skor posttest yang diperoleh siswa sebesar 89,1. Sementara peningkatan yang tidak terlalu menonjol terlihat pada aspek mekanik. Skor rata-rata pretest pada aspek mekanik yaitu sebesar 30,76 sedangkan skor rata-rata posttest adalah sebesar 65.38. Artinya peningkatan siswa pada aspek mekanik tidak terlalu besar dibandingkan peningkatan kemampuan menulis siswa pada aspek lain. Hasil uji $t$ kemampuan menulis teks eksplanasi siswa secara keseluruhan dapat dilihat pada tabel 3 di bawah ini yaitu sebagai berikut.

Tabel 3. Hasil Uji Perbedaan Dua Rerata Kemampuan Menulis Teks Eksplanasi

\begin{tabular}{lcc}
\hline & Pretest & Posttest \\
\hline Nilai rata-rata & 36.6 & 78 \\
Std. Deviation & 11.03 & 12.814 \\
Uji Normalitas & 0.08 & 0.25 \\
Uji Homogenitas & 0.356 & 0.356 \\
Uji t & 0.00 & 0.00 \\
\hline
\end{tabular}

Berdasarkan hasil uji $t$ pretest dan posttest kemampuan menulis teks eksplanasi siswa diperoleh hasil bahwa nilai rata-rata kemampuan menulis siswa pada kegiatan pretest sebesar 36,6 dengan simpangan baku sebesar 11,03 sedangkan nilai rata-rata posttest siswa sebesar 78 dengan simpangan baku sebesar 12,814. Setelah dilakukan uji normalitas pada skor pretest siswa menggunakan uji kolmogorov-smirnov diperoleh nilai signifikanisnya adalah $0,08>0,05$ artinya $\mathrm{H}_{0}$ diterima. Dengan demikian dapat disimpulkan bahwa data pretest kemampuan menulis teks eksplanasi siswa berdistribusi normal. Kemudian pada data posttest diketahui bahwa nilai signifikansi uji normalitasnya sebesar $0,25>0,05$ artinya kedua data tersebut berdistribusi normal.

Berdasarkan tabel 3, diketahui bahwa nilai signifikansi pada uji homogenitas sebesar 0,356 lebih besar dari taraf signifikansinya yaitu 0,05 $(0,356>0,05)$ artinya $\mathrm{H}_{0}$ diterima. Dengan demikian dapat disimpulkan bahwa data kelompok pretest dengan posttest memiliki varians yang sama atau data bersifat homogen.

Berdasarkan hasil uji dua rerata pretest dan posttest menggunakan pairedsample t-test diketahui bahwa $\mathrm{t}=-17.953$ dengan nilai signifikansinya adalah 0,00 lebih kecil dari $0,05(0,00<0,05)$ artinya $\mathrm{H}_{0}$ ditolak. Dengan demikian dapat disimpulkan bahwa terdapat perbedaan yang signifikan kemampuan menulis teks eksplanasi siswa antara sebelum dan sesudah diberikan treatment dengan menggunakan model multiliterasi kritis.

Secara umum, masing-masing indikator kemampuan menulis teks eksplanasi siswa mengalami peningkatan. Namun terdapat indikator kemampuan menulis yang peningkatannya tidak terlalu signifikan yaitu pada indikator aspek mekanik. Pada aspek mekanik, siswa masih belum mampu menggunakan ejaan dengan baik sesuai dengan pedomaan umum ejaan bahasa Indonesia.

\section{Kemampuan Menulis Teks Eksplanasi Menggunakan Model RADEC}

Berdasarkan hasil skor posttest, menunjukkan kemampuan menulis teks eksplanasi siswa lebih baik dibandingkan dengan hasil skor pretest. Pada tabel 1 dan tabel 2 di bawah ini, menunjukkan perbedaan kemampuan menulis teks eksplanasi siswa dilihat pada empat indikator yaitu struktur teks eksplanasi, isi, bahasa, dan aspek mekanik. Perbedaan tersebut dapat dilihat pada tabel berikut.

Tabel 4. Hasil Pretest

\begin{tabular}{|c|c|c|c|c|}
\hline & Struktur & Isi & Bahasa & Mekanik \\
\hline Mean & 48.68 & 51.31 & 51.97 & 40.78 \\
\hline Median & 50 & 50 & 50 & 50 \\
\hline Std. & 12.928 & 19.231 & 17.802 & 22.082 \\
\hline Deviation & & & & \\
\hline Variance & 167.141 & 369.844 & 316.945 & 216.927 \\
\hline Range & 50 & 50 & 50 & 50 \\
\hline Minimum & 25 & 25 & 25 & 25 \\
\hline Maximum & 75 & 75 & 75 & 75 \\
\hline
\end{tabular}
menunjukkan bahwa kemampuan awal siswa dalam menulis teks eksplanasi termasuk dalam kategori kurang. Skor minimum dari setiap aspek menulis teks 
eksplanasi yang diperoleh siswa sebesar 25, sedangkan skor maksimum dari setiap aspeknya sebesar 75. Aspek yang paling menonjol diantara empat indikator kemampuan menulis teks eksplanasi siswa adalah aspek struktur. Artinya kemampuan menulis teks eksplanasi siswa sesuai dengan struktur teks eksplanasi pada kegiatan pretest mendapatkan skor rata-rata tertinggi diantara aspek yang lainnya.

Tabel 5. Hasil Posttest

\begin{tabular}{lcccc}
\hline & Struktur & Isi & Bahasa & Mekanik \\
\hline Mean & 76.31 & 69.07 & 74.34 & 55.92 \\
Median & 75 & 75 & 75 & 50 \\
Std. & 22.471 & 22.082 & 21.345 & 22.082 \\
Deviation & & & & \\
Variance & 504.97 & 487.64 & 455.63 & 487.64 \\
Range & 75 & 75 & 75 & 75 \\
Minimum & 25 & 25 & 25 & 25 \\
Maximum & 100 & 100 & 100 & 100 \\
\hline
\end{tabular}

Berdasarkan data posttest pada tabel

2, diketahui bahwa terdapat peningkatan kemampuan menulis setelah diberikan pembelajaran menggunakan model RADEC. Skor maksimum yang semula mendapat skor 75, setelah diberikan treatment naik menjadi 100. Aspek yang paling menonjol diantara empat indikator kemampuan menulis teks eksplanasi siswa adalah aspek struktur. Peningkatan dari setiap indikator dapat dilihat pada gambar berikut.

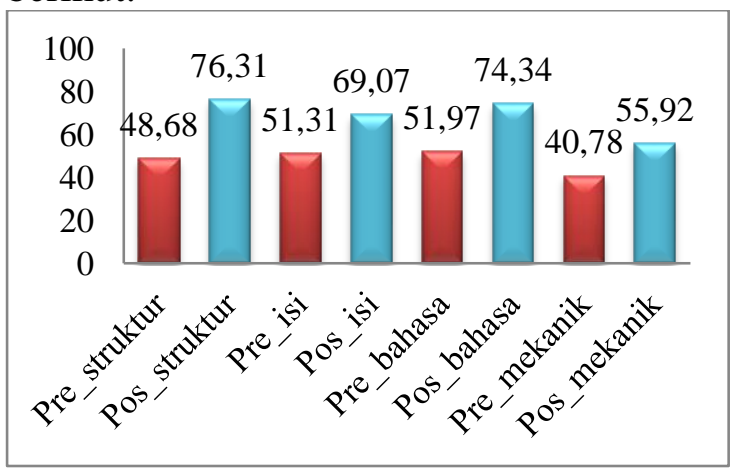

Gambar 2. Peningkatan Kemampuan Menulis Teks Eksplanasi

Berdasarkan gambar 2, data menunjukkan terjadi peningkatan pada setiap indikator kemampuan menulis teks eksplanasi. Peningkatan yang paling signifikan terjadi pada indikator struktur teks eksplanasi. Hal ini terlihat dari data pretest pada aspek struktur yaitu sebesar 48,68 sedangkan skor posttest sebesar
76.31. Sementara peningkatan yang tidak terlalu menonjol terlihat pada aspek mekanik. Skor rata-rata pretest pada aspek mekanik yaitu sebesar 40,78 sedangkan skor rata-rata posttest adalah sebesar 55.92. Artinya peningkatan siswa pada aspek mekanik tidak terlalu besar dibandingkan peningkatan kemampuan menulis siswa pada aspek lain.

Sekait dengan penjelasan di atas, kemampuan menulis teks eksplanasi secara keseluruhan dapat dilihat dari hasil uji dua rerata pretest dan posttest pada tabel 3 berikut.

Tabel 6. Pretest, Posttest dan Uji $t$ Kemampuan Menulis Teks Eksplanasi

\begin{tabular}{lll}
\hline & Pretest & Posttest \\
\hline $\mathrm{N}$ & 38 & 38 \\
Rata-rata & 48.1 & 68.9 \\
Std. Deviation & 13.546 & 19.521 \\
Uji Normalitas & 0.27 & 0.75 \\
Uji Homogenitas & 0.02 & 0.02 \\
Uji t' & 0.00 & 0.00 \\
\hline
\end{tabular}

Berdasarkan tabel di atas, telah diperoleh hasil bahwa nilai rata-rata pretest sebesar 48,1 dengan kategori kurang dan nilai rata-rata posstest sebesar 68,9 dengan kategori cukup. Berdasarkan uji normalitas yang dilakukan telah menunjukkan bahwa data tersebut semuanya berdistribusi normal tapi tidak homogen. Karena data tersebut tidak homogen, maka peneliti melanjutkan analisis data menggunakan uji $t^{\prime}$. dari hasil uji $t$ ' diperoleh hasil bahwa nilai signifikansinya adalah $0.000<0,05$ artinya $\mathrm{H}_{0}$ ditolak. Dengan demikian dapat disimpulkan bahwa terdapat perbedaan secara signifikan kemampuan menulis teks eksplanasi siswa antara sebelum dan sesudah diberikan treatment menggunakan model pembelajaran RADEC.

\section{Perbandingan Efektivitas Model Multiliterasi Kritis dengan Model RADEC Terhadap Kemampuan Menulis Teks Eksplanasi}

Untuk melihat model mana yang lebih efektif dalam meningkatkan kemampuan menulis teks eksplanasi siswa, maka peneliti menguraikannya pada bagian berikut. 
Tabel 7. Uji beda dua rerata pretest

\begin{tabular}{lcc}
\hline \multicolumn{1}{c}{ Pretest } & $\begin{array}{c}\text { Model } \\
\text { Multiliterasi Kritis }\end{array}$ & $\begin{array}{c}\text { Model } \\
\text { RADEC }\end{array}$ \\
\hline Nilai Rata-rata & 36.6 & 48.1 \\
Simpangan baku & 11.030 & 13.546 \\
Uji Normalitas & 0.83 & 0.278 \\
Uji homogenitas & 0,138 & 0.138 \\
Uji t & 0.00 & 0.00 \\
\hline \multicolumn{1}{c}{ Berdasarkan } & tabel di & atas,
\end{tabular}

didapatkan hasil bahwa nilai signifikansi pretest di kelas eksperimen 1 dan eksperimen 2 sebesar 0,00 artinya $0,00<0,05$. Dengan demikian dapat disimpulkan bahwa terdapat perbedaan yang signifikan kemampuan awal menulis teks eksplanasi siswa. Kemampuan awal menulis teks eksplanasi siswa di kelas eksperimen 2 lebih tinggi dibandingkan dengan kemampuan awal siswa di kelas eksperimen 1. Hal ini terlihat dari nilai ratarata pretest di kelas eksperimen 1 sebesar 36,6 sedangkan nilai di kelas eksperimen 2 sebesar 48,1. Selanjutnya, hasil posttest kemampuan menulis teks eksplanasi siswa setelah diberikan perlakuan dengan menerapkan model pembelajaran dapat dilihat pada tabel berikut.

Tabel 8. Uji beda dua rerata posttest

\begin{tabular}{lcc}
\hline \multicolumn{1}{c}{ Posttest } & $\begin{array}{c}\text { Model } \\
\text { Multiliterasi Kritis }\end{array}$ & $\begin{array}{c}\text { Model } \\
\text { RADEC }\end{array}$ \\
\hline Nilai Rata-rata & 78 & 68.9 \\
Simpangan baku & 12.814 & 19.521 \\
Uji Normalitas & 0.252 & 0.759 \\
Uji homogenitas & 0.008 & 0.008 \\
Uji t & 0.018 & 0.018 \\
\hline
\end{tabular}

Berdasarkan data pada tabel di atas, diperoleh hasil bahwa nilai signifikansi uji beda dua rerata posttest yaitu sebesar 0,018 artinya $0,018<0,05$. Dengan demikian dapat disimpulkan bahwa terdapat perbedaan yang signifikan kemampuan menulis teks eksplanasi siswa setelah diberikan perlakuan menggunakan model pembelajaran multiliterasi kritis yang diterapkan di kelas eksperimen 1 dan model RADEC yang diterapkan di kelas eksperimen 2. Temuan yang menarik dalam penelitian ini adalah kemampuan menulis teks eksplanasi siswa di kelas eksperimen yang sebelumnya mendapatkan nilai ratarata yang rendah, setelah diberikan perlakuan menggunakan model multiliterasi kritis terdapat peningkatan yang signifikan.

\section{Pembahasan}

Dari hasil analisis data, didapatkan hasil bahwa model multiliterasi kritis lebih efektif dalam meningkatkan kemampuan menulis teks eksplanasi siswa sekolah dasar. Hal ini dikarenakan model multiliterasi kritis mampu mendorong sisiwa untuk beroleh pemahman yang lebih terhadap konten atau materi yang akan ditulis dan mendorong siswa untuk memahami bahasa dari teks eksplanasi. Dalam hal ini, aspek kognitif siswa lebih berkembang melalui tahapan model multiliterasi kritis. Komponen kognitif memiliki peran yang cukup sentral dan berpengaruh secara signifikan dalam meningkatkan kemampuan siswa dalam menulis (Decker, Roberts, Roberts, \& Stafford, 2016).

Model multiliterasi kritis telah memberikan dampak yang positif kepada siswa melalui langkah-langkah pembelajaran yang menuntut siswa untuk berpikir secara ilmiah. Dampak dari kegiatan berpikir ilmiah yang diperkaya dengan multiliterasi akan memperkuat pengetahuan siswa, sehingga siswa beroleh pemahaman yang tinggi (Allison \& Goldston, 2018; Iyer \& Luke, 2010). Pengetahuan dan pemahaman siswa yang kuat mengenai sebuah teks dan ilmu pengetahuan yang dipelajari dapat memudahkan siswa dalam menuangkan ide yang dimilikinya kedalam bentuk tulisan (Alexander, DePalma, \& Ringer, 2016).

Tahapan model multiliterasi kritis diawali dengan curah gagasan. Kegiatan curah gagasan bertujuan untuk melihat sejauh mana pengetahuan siswa mengenai fenomena yang terjadi. Kegiatan curah gagasan memiliki dampak positif bagi perkembangan keterampilan siswa terutama keterampilan berkomunikasi. Keterampilan berkomunikasi merupakan salah satu keterampilan yang penting untuk dikuasai di abad ke-21 ini (Brinkley et. al., 2012; Morocco, et. al., 2008). 
Tahapan kedua model multiliterasi kritis adalah menetapkan masalah. Tahap menetapkan masalah siswa diminta untuk menetapkan masalah yang menurut mereka menarik untuk dikaji. Penetapan masalah dengan melibatkan siswa dalam pengambilan keputusan akan meningkatkan motivasi siswa dalam mengikuti proses pembelajaran dan membuat siswa menjadi lebih bertanggung jawab terhadap tugas-tugas yang harus dikerjakan (Bonyadi \& Zeinalpur, 2014).

Tahap ketiga model multiliterasi kritis adalah membaca teks. Pada tahap ini, siswa membaca teks untuk mengenal dan memahami permasalahan yang terjadi. Kegiatan membaca sebelum menulis ini dijadikan sebagai bekal pengetahuan siswa untuk kegiatan menulis. Kegiatan membaca untuk menulis memiliki dampak positif terhadap peningkatan kemampuan siswa dalam menulis (Soltani, \& Kheirzadeh, 2017).

Pada tahap keempat dan tahap kelima model multiliterasi kritis ini adalah tahap menemukan fakta dan opini, kemudian dilanjutkan tahap menguji fakta dan opini. Tahap ini mendorong siswa untuk berpikir secara kritis dalam mengumpulkan data berupa fakta tentang permasalahan yang terjadi. Kegiatan ini berdampak positif bagi kegiatan menulis siswa, sehingga tulisan yang dibuat oleh siswa benar-benar didasarkan pada fakta sebagaimana karakteristik isi dari teks eksplanasi itu sendiri yaitu isi penjelasan harus berdasarkan pada fakta.

Pada tahap keenam model ini adalah menetapkan fenomena. tahap ini siswa menentukan fenomena apa yang menurut siswa menarik untuk dijelaskan. Kegiatan menentukan fenomena ini melibatkan siswa dalam pengambilan keputusan. Pembelajaran menulis yang melibatkan siswa dalam proses pengambilan keputusan mengenai topik yang akan dibahas dan dijelaskan dalam bentuk teks eksplanasi dapat meningkatkan rasa percaya diri siswa, meningkatkan motivasi siswa dan siswa memiliki tanggung jawab untuk menyelesaikan tugasnya (Bonyadi \& Zeinalpur, 2014). Selanjutnya, peran guru sebagai fasilitator dalam pembelajaran menghendaki siswa untuk menjadi aktor dalam pembelajaran yang aktif sehingga pembelajaran menjadi lebih bermutu dan bermakna (Navehebrahim, 2011).

Tahap ketujuh model multiliterasi kritis adalah menganalisis fenomena dan teks eksplanasi. Tahap analisis ini memiliki dampak positif yaitu memperkuat pengetahuan siswa (Allison \& Goldston, 2018). Pemahaman siswa yang kuat tentang teks eksplanasi dan fenomena yang dikaji berdampak positif bagi kemampuan menulis siswa yaitu memudahkan siswa dalam menuangkan ide yang dimilikinya kedalam bentuk tulisan (Alexander, DePalma, \& Ringer, 2016).

Tahap terakhir model multiliterasi kritis adalah memproduksi karya. Karya yang dibuat oleh siswa dalam hal ini adalah teks eksplanasi. Fenomena yang dijelaskan dalam teks eksplanasi adalah fenomena yang sudah ditentukan dan dikaji oleh siswa. Teks eksplanasi yang ditulis siswa dalam pembelajaran ini tidak hanya sekedar berbentuk tulisan biasa, melainkan teks eksplanasi yang dibuat siswa ditulis dalam bentuk yang inovatif dan menarik seperti mini book, buku zig-zag, oval book. Tulisan teks eksplanasi yang dibuat siswa dibubuhi dengan gambar dan paduan warna yang menarik. Hal tersebut dilakukan dengan tujuan untuk membuat pembelajaran menjadi lebih menarik dan mengakomodasi keberagaman yang dimiliki oleh siswa. Pembelajaran yang dapat mengakomodasi keberagaman siswa merupakan pembelajaran yang bermakna bagi siswa karena siswa beroleh pengalaman yang berharga (Altas, 2014; Hesterman, 2011).

Model pembelajaran multiliterasi kritis telah terbukti dapat meningkatkan kemampuan menulis teks eksplanasi siswa. Berdasarkan penelitian sebelumnya juga menunjukkan bahwa model multiliterasi kritis berpengaruh secara signifikan terhadap kemampuan menulis siswa (Susilo 
\& Ramdiati, 2019; Dafit, 2017; Nurhalimah, 2016; Iskandar, Abidin \& Yunansah 2016). Selain itu, model multiliterasi kritis juga dapat meningkatkan kompetensi ekologis dan mengembangkan karakter siswa (Irianto, Herlambang, \& Yunansah, 2018).

\section{KESIMPULAN}

Berdasarkan hasil penelitian tentang efektivitas model multiliterasi kritis dengan model RADEC terhadap kemampuan menulis teks eksplanasi siswa diperoleh hasil bahwa model multiliterasi kritis lebih efektif dalam meningkatkan kemampuan menulis teks eksplanasi siswa. Hal ini terlihat dari hasil uji t posttest di kelas eksperimen 1 dan eksperimen 2 yaitu nilai sig $=0.018$ artinya terdapat perbedaan yang signifikan kemampuan menulis teks eksplanasi siswa antara siswa yang mendapatkan pembelajaran menggunakan model multiliterasi kritis dengan siswa yang mendapatkan pembelajaran menggunakan model RADEC. Penelitian ini berimplikasi pada proses pembelajaran yang menuntut siswa untuk aktif dan mendorong siswa untuk mencapai penguasaan kompetensi abad ke-21. Namun pada penelitian ini masih terdapat beberapa kelemahan yaitu siswa masih belum menguasai ejaan dalam tata tulis. Sehingga peneliti merekomendasikan bagi peneliti selanjutnya untuk melakukan sebuah terobosan inovasi untuk meningkatkan pemahaman dan keteranpilan siswa dalam penggunaan ejaan.

\section{DAFTAR PUSTAKA}

Abidin, Y. (2012). Pembelajaran Bahasa Berbasis Pendidikan Karakter. Bandung: Refika Aditama.

Abidin, Y. (2015). Pembelajaran Multiliterasi Sebuah Jawaban atas Tantangan Pendidikan Abad Ke-21 dalam Konteks Keindonesiaan. Bandung: Refika Aditama.
Akkaya, N., \& Kirmizi, F. S. (2010). Relationship between attitudes to reading and time allotted to writing in primary education. Procedia Social and Behavioral Sciences, 2(2), $4742-$

4746.https://doi.org/10.1016/j.sbspr o.2010.03.761.

Alexander, K. P., DePalma, M. J., \& Ringer, J. M. (2016). Adaptive Remediation and the Facilitation of Transfer in Multiliteracy Center Contexts. Computers and Composition, 41, 32-45. https://doi.org/10.1016/j.compcom. 2016.04.005.

Allison, E., \& Goldston, M, J. (2018). Modern Scientific Literacy: A Case Study of Multiliteracies and Scientific Practices in a Fifth Grade Classroom, 27, 270-283. https://doi.org/10.1007/s10956017-9723-z.

Altas, B. (2014). A Case Study of Multimodal Presentation of Selected Stage Play Literature in a Multimedia Environment. Procedia - Social and Behavioral Sciences, 116 , 1726-1734. https://doi.org/10.1016/j.sbspro.201 4.01.463.

Anderson, M \& Anderson, K. (1997a). Text Types in English 1. Melbourne: Macmillan Education Australia.

Andyani, N., Saddhono, K., \& Mujyanto, Y. (2016). Peningkatan Kemampuan Menulis Teks Eksplanasi Dengan Menggunakan Media Audiovisual Pada Siswa Sekolah Menengah Pertama. Jurnal Penelitian Bahasa, Sastra Indonesia dan Pengajarannya, 4 (2), pp. 161174.

Bakry, M. S., \& Alsamadani, H. A. (2015). Improving the Persuasive Essay Writing of Students of Arabic as a Foreign Language (AFL): Effects of Self-Regulated Strategy Development. Procedia - Social 
and Behavioral Sciences, 182, 8997.

https://doi.org/10.1016/j.sbspro.201 5.04.742.

Bonyadi, A., \& Zeinalpur, S. (2014). Perceptions of Students Towards Self-selected and Teacher-assigned Topics in EFL Writing. Procedia Social and Behavioral Sciences, 98, 385-391.

https://doi.org/10.1016/j.sbspro.201 $\underline{4.03 .430}$.

Brinkley, M., et. al. (2012). Defining Twenty-First Century Skills. dalam Griffin, P. Assesment and Teaching of $21^{\text {st }}$ Century Skills. New York: Springer.

Cahyani, I. (2012). Pembelajaran Menulis Berbasis Karakter dengan Pendekatan Experiental Learning. Bandung: Program Studi Pendidikan Dasar SPS UPI.

Celce-Murcia, M. (2001). Teaching English as a second or foreign language (3th ed.). Boston: Heinle $\&$ Heinle.

Dafit, F. (2017). Keefektifan Kemampuan Menulis Kreatif Siswa SD Dengan Model Pembelajaran Multiliterasi. Gerakan Aktif Menulis, 5, Hlm. 4957.

Decker, S. L., Roberts, A. M., Roberts, K. L., \& Stafford, A. L. (2016). Cognitive components of developmental writing skill, 53(6). https://doi.org/10.1002/pits.

Derewianka, B. (1990). Exploring How Text Work. Newtown: PETA.

Education Department of Western Australia. (1997a). Writing resource book. Port Melbourne: Henemann.

Emilia, E. (2012). Pendekatan GenreBased dalam Pengajaran Bahasa Inggris: Petunjuk untuk Guru. Bandung: Riqi Press.
Freire, P. (2005). Education for Critical Consciousness. London: Continuum.

Gerot, L. \& Wignell. (1995). Making Sense of Functional Grammar. Australia: Gerd Stabler.

Giampapa, F. (2010). Multiliteracies, Pedagogy and Identities: Teacher and Student Voices rom a Toronto Elmentary School. Canadian Journal of Education. 33,2 (2010). 407-431.

Graham, S., \& Hall, T. E. (2016). Writing and Writing Difficulties from Primary Grades to College. Learning Disability Quarterly, 39(1), 3-4. https://doi.org/10.1177/073194871 5592154.

Hartati, T. \& Cuhariah, Y. (2015). Pendidikan Bahasa dan Sastra Indonesia. Bandung: UPI PRESS.

Hesterman, S. (2011). A contested space: The dialogic intersection of ICT, multiliteracies, and early childhood. Contemporary Issues in Early Childhood, 12(4), 349-361. https://doi.org/10.2304/ciec.2011.1 2.4.349.

Irianto, D. M., Herlambang, Y., \& Yunansah, H. (2018). Multiliteration Model Based on Ecopedagogy Approach in Improving Ecological Intelligence and Developing Characters. Proceedings of International Conference on Elementary Education. Bandung: 19-20 September 2018. Hal. 135-142.

Iskandar, C. C., Abidin, Y., \& Yunansah, H. (2016). Penggunaan Model Multiliterasi Kritis Untuk Meningkatkan Kemampuan Siswa Dalam Menulis Karangan Argumentasi. Jurnal PGSD Kampus Cibiru, 4(3).

Iyer, R., \& Luke, C. (2010). Multimodal, Multiliteracies: Text and 
Literacies for the $21^{\text {st }}$ Century. Dalam Pullen \& Cole (Eds.). Multiliteracies and Technology Enhanced Education: Social Practice and the Global Classroom. New York: Information Science Reference (an imprint of IGI Global).

Joyce, B. Weil, M. \& Calhoun, E. (2011). Models of Teaching. Yogyakarta: Pustaka Pelajar.

Kemendikbud. (2014). Buku Guru Bahasa Indonesia Wahana Pengetahuan. Jakarta: Kemendikbud.

Knapp, P \& Watkins. (2005). Genre, Text, Grammar Technologies for Teaching and Assessing Writing. Sydney: University of New South Wales.

Lagur, M. N. (2016). Kemampuan Menulis Teks Eksplanasi dengan Menggunakan Media Gambar Seri Siswa Kelas VII SMP Negeri 2 Turi, Sleman, Yogyakarta Tahun Ajaran 2015/2016. Skripsi Tidak Diterbitkan. Yogyakarta: Universitas Negeri Yogyakarta.

Mahsun, (2014). Teks dalam Pembelajaran Bahasa Indonesia. Jakarta: Rajawali Pers.

Morocco, C. C., et. al (2008). Supported Literacy for Adolescents: Transforming Teaching and Content Learning for The TwentyFirst Century. San Fransisco: Jossey-Bass Awiley Imprint.

Navehebrahim, M. (2011). Multiliteracies Approach to empower learning and teaching engagement. Procedia Social and Behavioral Sciences, 29, 863-868.

https://doi.org/10.1016/j.sbspro.201 1.11 .315 .

Nurhalimah, S. (2016). Perbandingan Efektivitas Model Multiliterasi Kritis dan Model Menulis Otentik Terhadap Kemampuan Menulis Teks Persuasi Siswa Sekolah Dasar.
Skripsi Tidak Diterbitkan. Bandung: Universitas Pendidikan Indonesia.

Özdemir, E., \& Aydın, S. (2015). The Effects of Wikis on Motivation in EFL Writing. Procedia - Social and Behavioral Sciences, 191, 23592363.

https://doi.org/10.1016/j.sbspro.201 5.04.241.

Pardo, L. S. (2006). The role of context in learning to teach writing: What teacher educators need to know to support beginning urban teachers. Journal of Teacher Education, 57(4), 378-394. https://doi.org/10.1177/002248710 $\underline{6291563 .}$.

Paul, D. (2007). Teaching English to Children in Asia. Hongkong: Pearson Education Asia Limited.

Pemerintah Republik Indonesia. (2003). Undang-Undang Republik Indonesia Nomor 20 Tahun 2003 tentang Sistem Pendidikan Nasional. Sekretariat Negara Republik Indonesia. Jakarta.

Priyatni, E.T. (2014). Desain Pembelajaran Bahasa Indonesia dalam Kurikulum 2013. Jakarta: Bumi Aksara.

Republik Indonesia, Peraturan Mentri Pendidikan dan Kebudayaan, Nomor 24, 2016, tentang Kompetensi Inti dan Kompetensi Dasar Pelajaran pada Kurikulum 2013 pada Pendidikan Dasar dan Pendidikan Menengah.

Rose, D. (2007). Reading to learn learning to read. Assessing Students Writing. Melbourne: Catholic Education Office of Melbourne.

Seah, L. H. (2015). Understanding the Conceptual and Language Challenges Encountered by Grade 4 Students When Writing Scientific Explanations. 
https://doi.org/10.1007/s11165-

015-9464-z.

Silvers, P., Shorey, M., \& Crafton, L. (2010). Critical literacy in a primary multiliteracies classroom: The hurricane group. Journal of Early Childhood Literacy, 10(4), 379409.

https://doi.org/10.1177/146879841 0382354.

Soltani, A., \& Kheirzadeh, S. (2017). JOURNAL OF LANGUAGE AND LINGUISTIC STUDIES Exploring EFL students' use of writing strategies and their attitudes towards reading-to-write and writing-only tasks, 13(2), 535-560.

Sopandi, W. (2017). The quality improvement of learning processes and achievements through the readanswer-discuss-explain-and create learning model implementation. Proceeding 8th Pedagogy International Seminar 2017: Enhancement of Pedagogy in Cultural Diversity Toward Excellence in Education, 8(229), 132-139.

Sopandi, W., \& Handayani, H. (2019). The Impact of Workshop on Implementation of (RADEC) Learning Model on Pedagogic Competency of Elementary School Teachers. International Conference of Innovation in Education (ICoIE) 178, pp. 7-11.

Susilo, S. \& Ramdiati, T. (2019). Penerapan Model Multiliterasi untuk Meningkatkan Keterampilan Menulis Karangan Persuasi pada Mata Pelajaran Bahasa Indonesia di Sekolah Dasar. Jurnal Cakrawala Pendas, 5 (1), pp. 24-31.

Tarigan, H.G. (2013). Menulis Sebagai Suatu Keterampilan Berbahasa. Bandung: Angkasa. 